\title{
THE PRESENCE OF PROTEASE ACTIVITY IN THE RECTAL FLUID OF ATTINE ANTS
}

\author{
JOAN STADLER MARTIN and MICHAEL M. MARTIN
}

The Department of Chemistry, University of Michigan, Ann Arbor, Michigan 48104

(Received 19 August 1969)

\begin{abstract}
The rectal fluid of twenty-two species of ants, including seven species of Attini, seven species of non-attine Myrmicinae, and eight species of Formicinae was assayed for proteolytic enzyme activity. Significant activity was present in the rectal fluid of all of the attines and only in the attines. Some implications of these results are discussed.
\end{abstract}

\section{INTRODUCTION}

THE ATTINE ants culture a fungus in their nests and exploit this fungus as their primary and probably sole food source (BELT, 1874; MülLER, 1874; WHEELER, 1907; WeBER, 1958, 1966). All of the attines, from the primitive genus Cyphomyrmex to the highly evolved genera Acromyrmex and Atta, characteristically defaecate on their fungus gardens and on substrate which they are preparing for incorporation into their gardens (HüBER, 1905; WEBER, 1958, 1966). The significance of this interesting behaviour has been the subject of much speculation (WEBER, 1947, 1958, 1966). We have recently established that the faecal material of Atta colombica tonsipes contains proteolytic enzymes, and that the fungus cultured by $A$. c. tonsipes is lacking the full complement of such enzymes necessary to make efficient use of polypeptides present in a culture medium (MARTIN and MarTin, 1970). We concluded, therefore, that the deposition of faecal material on the fungus garden enhances the competitive status of the fungus by compensating for a critical metabolic deficiency in its metabolic apparatus.

The only other insects which have been reported to excrete proteolytic enzymes are the blowfly larvae Lucilia sericata, L. cuprina, and Phormia regina (Hobson, 1931a, b; Waterhouse and IrZYKIEWICZ, 1957; BRoOKes, 1961). However, there have been so few studies of the enzymatic properties of insect excreta that it was impossible to say whether the excretion of proteolytic enzymes is widespread, or a characteristic peculiar to a few special groups of insects. This paper is a report on a survey of proteolytic activity in the midgut and rectal contents of twenty-two species of ants, comparing seven attine species with seven non-attine myrmicines and eight formicines.

The ants

\section{MATERIALS AND METHODS}

Live ants were the source of all materials used in this study. The attine species, Atta colombica tonsipes, A. cephalotes, A. sexdens, Acromyrmex octospinosus, 
A. lobicornis, Sericomyrmex urichi, and Trachymyrmex septentrionalis all came from captive colonies maintained by Professor Neal Weber at the Department of Biology, Swarthmore College. Lasius alienus, L. pallitarsis, Polyergus breviceps, Formica montana, $F$. ulkei, $F$. obscuripes, $F$. pergandei, Myrmica monticola, $M$. emeryana, and $M$. brevinodis were collected in the vicinity of the Oakville Prairie Field Station of the University of North Dakota. Identifications were made by Professor Paul Kannowski, Department of Biology, University of North Dakota. Acanthomyops claviger, Aphaenogaster rudis, and Crematogaster cerasi were collected in Ann Arbor, Michigan, in late June, and Aphaenogaster treatae and Crematogaster lineolata were collected at the E. S. George Reserve, Livingston County, Michigan, in late June. Identifications were made by Dr. Mary Talbot, Lindenwood College, St. Charles, Missouri.

\section{Dissection}

Gasters of live ants were dissected under distilled water to free the midgut and rectum. The hindgut was severed, and the midgut and rectum were placed in separate dissection dishes. The contents of each were then removed with a very fine glass needle attached to a syringe. Separate forceps and needles were used for the rectum and midgut in order to preclude any possibility of contamination. The contents were kept on ice until analysed. For all of the attine species and for Acanthomyops claviger both the midgut and rectal content samples were pooled from five ants. For the two species of Aphaenogaster, the midgut sample was derived from five ants, the rectal sample from ten. For all others, ten ants were used to obtain both midgut and rectal samples.

The length and diameter of both midgut and rectum were determined using an ocular micrometer. Volumes were calculated assuming cylindrical geometry. Table 3 was constructed from measurements made on four to six ants of each species.

\section{Proteolytic enzyme assay}

Protease activity was assayed using the Azocoll procedure (Calbiochem, Los Angeles, California). The contents of the midgut or rectum were transferred into a test-tube containing $15 \mathrm{mg}$ of Azocoll by repeated rinsing with $1 \mathrm{ml}$ of $0.05 \mathrm{M}$ phosphate buffer ( $\mathrm{pH} 6.65 \pm 0.03)$ and enough distilled water to make the final volume $3 \mathrm{ml}$. The tube was incubated while being stirred with a small magnetic stirring bar for $20 \mathrm{~min}$ at $37^{\circ} \mathrm{C}$. The mixture was filtered rapidly through a small course sintered glass funnel into a colorimeter tube. Absorbence was read on a Coleman Jr. spectrophotometer at $580 \mathrm{~m} \mu$. Distilled water controls were run.

\section{RESULTS}

The midgut and rectal contents of seven species of attines, representing four different genera, were assayed for proteolytic enzyme activity. In every species the level of protease activity was several times greater in the rectal contents than in the midgut contents (Table 1). The midgut and rectal contents of fifteen nonattine species, representing three genera from the subfamily Myrmicinae, to which 
TABLE 1-Proteol YTIC ENZYME ACTIVITY OF THE MIDGUT AND RECTAL CONTENTS OF ATTINE ANTS

\begin{tabular}{lcc}
\hline \multirow{2}{*}{\multicolumn{1}{c}{ Species }} & \multicolumn{2}{c}{ Activity/ant* } \\
\cline { 2 - 3 } & Midgut & Rectum \\
\hline Atta colombica tonsipes & $55-185$ & $355-550$ \\
A. cephalotes & 110 & 505 \\
A. sexdens & 100 & 350 \\
Acromyrmex octospinosus & $55 \dagger$ & 235 \\
A. lobicornis & $60 \dagger$ & 810 \\
Sericomyrmex urichi & 125 & 500 \\
Trachymyrmex septentrionalis & 55 & 715 \\
\hline
\end{tabular}

* Activity expressed in terms of the number of $\eta g$ of fungal protease (Sigma, Type VI) which exhibited comparable activity in the Azocoll assay.

$\dagger$ Entire midguts were used instead of just contents. The dissected midguts were homogenized by hand, and the protease assay conducted on the entire homogenate.

TABle 2-Proteolytic enzYMe ACtivity of THE Midgut and ReCtal contents of NON-ATTINE ANTS

\begin{tabular}{lcc}
\hline & \multicolumn{2}{c}{ Activity/ant* } \\
\cline { 2 - 3 } \multicolumn{1}{c}{ Species } & Midgut & Rectum \\
\hline A. Subfamily Formicinae & & \\
Acanthomyops claviger & 200 & $\leqslant 5$ \\
Lasius alienus & 100 & $\leqslant 5 \dagger$ \\
L. pallitarsis & 145 & $\leqslant 5$ \\
Polyergus breviceps & 195 & $\leqslant 5$ \\
Formica montana & 100 & $\leqslant 5$ \\
F. ulkei & 140 & $\leqslant 5$ \\
F. obscuripes & 235 & $\leqslant 5$ \\
F. pergandei & $60-125$ & $\leqslant 5-20$ \\
B. Subfamily Myrmicinae & & \\
Myrmica monticola & 90 & $\leqslant 5$ \\
M. emeryana & 300 & $\leqslant 5$ \\
M. brevinodis & 70 & 25 \\
Crematogaster cerasi & 200 & $\leqslant 5$ \\
C. lineolata & 185 & 25 \\
Aphaenogaster treatae & 1800 & 40 \\
A. rudis & 600 & 20 \\
\hline
\end{tabular}

* Activity expressed in terms of the number of $\eta \mathrm{g}$ of fungal protease (Sigma, Type VI) which exhibited comparable activity in the Azocoll assay. The lower limit of detection was about 5 ig/ant.

$\dagger$ Entire rectums were used instead of rectal contents. The dissected rectums were homogenized by hand and the protease assay conducted on the entire homogenate. 
the Attini also belong, and four genera from the subfamily Formicinae were also examined (Table 2). The contrast between the attines and the non-attines is striking. In most of the non-attines no proteulytic activity whatsoever could be detected in the rectal fluid. In the five species in which some activity was detected, it was much less than that of the midgut. In no case was rectal activity greater than, or even comparable to, midgut activity. 'To the extent that this survey is representative it would appear that the excretion of faecal material exhibiting significant protease activity is characteristic of and peculiar to the attine ants.

The attines and the non-attines also differ in the relative volumes of material present in the rectum and midgut (Table 3 ). In every non-attine species examined the average volume of the midgut is greater than the average volume of the rectum.

TABLE 3-The volumes OF Midguts AND RECTUMS OF various ANT SPECIES

\begin{tabular}{|c|c|c|c|c|}
\hline \multirow[b]{2}{*}{ Species } & \multicolumn{2}{|c|}{ Midgut } & \multicolumn{2}{|c|}{ Rectum } \\
\hline & $\begin{array}{l}\text { Av. vol. } \\
(\mu l)\end{array}$ & $\begin{array}{c}\text { Range } \\
(\mu \mathrm{I})\end{array}$ & $\begin{array}{c}\text { Av. vol. } \\
(\mu l)\end{array}$ & $\begin{array}{l}\text { Range } \\
(\mu \mathrm{l})\end{array}$ \\
\hline Lasius alienus & 0.20 & $0 \cdot 17-0 \cdot 26$ & 0.02 & $0.01-0.03$ \\
\hline L. pallitarsis & $0 \cdot 13$ & $0.06-0.22$ & 0.08 & $0 \cdot 06-0 \cdot 11$ \\
\hline Polyergus breviceps & 0.33 & $0 \cdot 27-0.37$ & $0 \cdot 30$ & $0 \cdot 19-0.39$ \\
\hline Formica montana & 0.44 & $0.13-0.66$ & $0 \cdot 13$ & $0.06-0.24$ \\
\hline F. ulkei & 1.95 & $1 \cdot 34-2 \cdot 67$ & 0.96 & $0 \cdot 47-1 \cdot 44$ \\
\hline F. obscuripes & $1 \cdot 11$ & $0 \cdot 76-1 \cdot 37$ & 0.52 & $0-16-0 \cdot 80$ \\
\hline$F$. pergandei & 0.43 & $0.24-0.55$ & 0.27 & $0 \cdot 13-0 \cdot 44$ \\
\hline Myrmica monticola & $0 \cdot 11$ & $0 \cdot 07-0.16$ & 0.09 & $0.07-0.11$ \\
\hline M. emeryana & $0 \cdot 18$ & $0 \cdot 11-0.24$ & $0 \cdot 10$ & $0 \cdot 03-0 \cdot 17$ \\
\hline M. brevinodis & $0 \cdot 17$ & $\dot{0} \cdot 07-0.33$ & $0 \cdot 14$ & $0.03-0.29$ \\
\hline Crematogaster cerasi & $0 \cdot 15$ & $0.06-0.24$ & 0.04 & $0.01-0.06$ \\
\hline C. linevlata & 0.08 & $0.06-0.15$ & 0.04 & $0.02-0.08$ \\
\hline Aphaenogaster treatae & $0 \cdot 34$ & $0 \cdot 24-0.50$ & 0.08 & $0.04-0.13$ \\
\hline A. rudis & $0 \cdot 34$ & $\begin{array}{ccc}0.20 & 0.50\end{array}$ & 0.10 & $0.04-0.22$ \\
\hline Alla colombica tonsipes & $0 \cdot 14$ & $0 \cdot 07-0 \cdot 18$ & $0 \cdot 31$ & $0.07-0.54$ \\
\hline A. cephalotes & 0.09 & $0.04-0.18$ & $0 \cdot 21$ & $0.15-0.29$ \\
\hline A. sexdens & $0 \cdot 27$ & $0.15-0.44$ & $0 \cdot 16$ & $0.07-0.37$ \\
\hline Acromyrmex oclospinosus & $0 \cdot 20$ & $0 \cdot 08-0.38$ & 0.26 & $0 \cdot 15-0 \cdot 37$ \\
\hline A. lobicornis & $0 \cdot 20$ & $0.18-0.22$ & 0.64 & $0.55-0.72$ \\
\hline Sericomyrmex urichi & $0 \cdot 19$ & $0 \cdot 15-0.24$ & $0 \cdot 12$ & $0 \cdot 09-0 \cdot 15$ \\
\hline Trachymryrmex septentrionalis & 0.09 & $0 \cdot 06-0 \cdot 11$ & $0 \cdot 14$ & $0.11-0.16$ \\
\hline
\end{tabular}

By contrast, in five of the seven attine specics the opposite is true; the average rectal volume is greater than the average midgut volume. The greater engorgement of the rectum of the attine ants doubtless reflects the restrictions on their defaecation behaviour. The faecal material of the attines plays a key rôle in the maintenance of their fungus cultures, and it is believed that the attines defaecate only on the fungus gardens (WEBER, 1966). Hence, an attine ant engaged in activities distant from the nest will necessarily build up large quantities of faecal 
material which must be retained in the rectum until return to the nest. A species without such restricted defaecation behaviour would presumably be able to defaecate more frequently and hence would store a smaller volume of faecal material in the rectum.

\section{DISCUSSION}

The major objective of this study was to establish whether the excretion of faecal material exhibiting significant protease activity is a common characteristic of ants in general. Clearly it is not. Indeed, in this limited survey, this characteristic is exhibited exclusively by the attine species examined. Since none of the fungus-growers examined belong to primitive genera, we cannot be certain that protease excretion is characteristic of the entire tribe of Attini. A study of the faecal material of primitive attines and non-attine myrmicines closely related to the attines would be of interest with respect to the question of the evolutionary origin of the fungus-growing ants. It might reveal whether the excretion of proteolytic enzymes was a characteristic of attine progenitors which permitted the fungus-growing habit to develop, or whether it was a characteristic which developed after the first fungus-growers had appeared, and which played a rôle in directing subsequent evolution and speciation.

Enzyme production is an energy-consuming process. Hence, as a general rule the excretion of digestive enzymes would be a wasteful and maladaptive practice. Two quite unrelated groups of insects, the fungus-growing ants and blowfly larvae, excrete active proteolytic enzymes in significant amounts, and in both groups the excreted enzyme serves a useful function to the organism. In the attines it benefits a symbiotic partner which returns the favour by providing the ants with a food supply, and in the blowfly it serves an extra-intestinal digestive function. If faecal enzymes are discovered in other groups, it is likely that the excretory material will be found to play some important rôle in their ecology.

Most digestive enzymes in insects are produced in the midgut, which is the site of primary digestion. Presumably, therefore, the proteolytic enzymes in the rectal fluid of the attine ants are simply digestive enzymes from the midgut which have accumulated in the rectum, although a microbial origin has not been ruled out. The contrasting enzymatic properties of the faecal material of the attine and nonattine ants raise two interesting and fundamental questions. What is the fate of the digestive enzymes in those insects which do not have proteolytic enzymes in their rectal fluid, and how do the attines spare their midgut enzymes from this fate? Neither question can be answered at the present time.

Acknowledgements-We wish to thank the National Institutes of Health for a grant (AI-07386) and the Sloan Foundation for a fellowship which supported most of this work. We wish to thank Professor NEAL WEBER for his hospitality at Swarthmore, and for his generosity in making his valuable material available to us, and Professor PAUL KanNowskI for making the Oakville Prairie Field Station of the University of North Dakota available to us, and for his considerable help during our stay there. Finally, we wish to thank Dr. MARY TALBOT for helping us find and identify ants of the Ann Arbor area. 


\section{REFERENCES}

BeLT T. (1874) The Naturalist in Nicaragua. London.

Brookes V. J. (1961) Partial purification of a proteolytic enzyme from an insect, Phormia regina. Biochim. biophys. Acta 46, 13-21.

Hobson R. P. (1931a) Studies on the nutrition of blowfly larvae-I. Structure and function of the alimentary tract. F. exp. Biol. 8, 109-123.

Hobson R. P. (1931b) On an enzyme from blowfly larvae (Lucilia sericata) which digests collagen in alkaline solution. Biochem. F. 25, 458-463.

HÜBER J. (1905) Über die Koloniengrundung bei Atta sexdens. Biol. Zbl. 25, 606-619, 625-635.

Martin M. M. and Martin J. S. (1970) The biochemical basis for the symbiosis between the ant, Atta colombica tonsipes, and its food fungus. F. Insect Physiol. 16, 109-119.

MüLLER F. (1874) The habits of various insects. Nature, Lond. 10, 102-103.

WATERHOUSE D. F. and IRZYKIEWICZ H. (1957) An examination of proteolytic enzymes from several insects for collaginase activity. F. Insect Physiol. 1, 18-22.

WeBER N. A. (1947) Lower Orinoco River fungus-growing ants. Bol. Ent. venezol. 6, 143-161.

Weber N. A. (1958) Evolution in fungus-growing ants. Proc. 10th int. Congr. Ent. (1956) 2, 459-475.

WeBER N. A. (1966) Fungus-growing ants. Science, Wash. 153, 587-604.

WhEELER W. M. (1907) The fungus-growing ants of North America. Bull. Am. Mus. nat. Hist. 23, 669-807. 